\title{
Media freedom vs. culture, history, foreign influences, and technologies: A comparative analysis of China and Myanmar
}

\author{
Manh-Tung Ho $\mathbf{H o}^{1,2,3}$ \\ ${ }^{1}$ Ritsumeikan Asia Pacific University, Beppu, Oita Prefecture, 874-8577, Japan \\ ${ }^{2}$ Institute of Philosophy, Vietnam Academy of Social Sciences, 59 Lang Ha St., Hanoi, 1-100000, \\ Vietnam \\ ${ }^{3}$ AI for Social Data Lab, Vuong \& Associates, Hanoi, 100000 Vietnam
}

\section{Email: tungmanhho@gmail.com}

\begin{abstract}
As China and Myanmar both have a history of political repression and are undergoing significant changes in the media landscape due to the rise of new technologies, a study on the issue of media freedom in the two countries could draw out some important implications. This paper looks at the structures and trends in the media environment of the two countries in recent history. Through an analysis of these factors, the paper attempts to outline the extent to which the media is free in China and Myanmar. Finally, as the two countries present a case study for how media freedom is shaped, the various factors that shape the extent of media freedom will be discussed: internal political environment, culture and history, foreign influences, and technologies.
\end{abstract}

Key words: Media freedom, China, Myanmar, politics, media environments.

\section{Introduction}

China and Myanmar, which are in the Asia Pacific region, provide an interesting case study for a comparative analysis on the issue of media freedom. In terms of similarities, both China and Myanmar have had a history of political repression, which is still affecting the media in each country until now. For China, it has been under the rule of the Communist Party of China (CPC) since 1949 and started open-doors policy since the 1970s. For Myanmar, the country was under the military rule for 50 years and is currently under democratic transition (Kajimoto, 2016; Than, 2015). Recently, they are both going through many changes in the media landscape due to the emergence of new technologies. China's internet penetration is $53.2 \%$, while it is only $25.1 \%$ for Myanmar (Freedom House, 2018). According to Freedom House (2018), China has a lower score than Myanmar (14/100 vs. 31/100); the press and the internet in both countries are considered to be unfree.

In terms of differences, China is more advanced in terms of technological control and has a much bigger population, while Myanmar is more democratic. These similarities and differences make a comparison of the extent of media freedom in China and Myanmar interesting. And as China and Myanmar possess many characteristics that other countries in the Asia Pacific also share, the comparative analysis will also be beneficial for the future of scientific exploration the issue of media freedom in other emerging economies in the regions (Vuong, 2018, 2019) 


\section{Literature Review}

\section{Internal political environment and media freedom}

Over the years, the relationship between media freedom and politics has been a hot topic for researchers all over the world. In this section, we will look at past studies and understand the dynamics in the relationship between media freedom and politics.

The research in this area shows there is a two-way relationship between media freedom and politics. In 2017, the historian Niall Ferguson published a book called The Square and the Tower: Networks, Hierarchies, and the Struggle for Global Power, in which he argued the rise of new media, especially those that give people a new way to network, tend to lead to political polarization. His prime examples are the birth of the printing press in 1450 and our modern social media platforms (Facebook, Twitter, etc.) (Ferguson, 2017). The former led to the rise of sectarian conflicts between Lutheranism and the Catholic Church (Carlin, 2013). The latter has led to the rise of right-wing populism and political polarization we are witnessing today.

Empirical studies on the relationship between media and politics have generally shown that media freedom tends to lead to better political rights. Research by Dutta and Roy (2016) has pointed out press freedom, by itself, could put certain limits to corruption, even in countries where media coverage is not particularly large. In 2007, Apocada showed that an increase in access to media led to better human rights records (Apocada, 2007).

As media freedom could influence politics, the political context could also influence the degree to which the media is free. Stier (2015), in an empirical analysis on the level of media freedom associated with different political regimes in 149 countries from 1993 to 2010, has found that media is most free in democracies. However, among autocratic regimes, there are different levels of media freedom. Electoral autocracies, monarchies, and military regimes have freer media than communist ideocracies. For the non-ideological one-party regime, media freedom tends to be of intermediate level. In 2016, in an attempt to explain the autonomy of media in China, a group of researchers at Sun Yat-sen University argued that the agenda divergence of the local authority with the central authority in China had given more autonomy for local media practitioners in China (Guan, Xia \& Cheng, 2017).

\section{Foreign factors and media freedom}

Another subject of much scholar inquiry is the role of foreign factors in shaping the extent of media freedom in particular and the media in general. In 2002, a comparative analysis on journalism ethics of Europe and the Islamic world showed that there is universalization in formal media ethics throughout the last decades (Hafez, 2002). In 2004, research by Herscovitz had shown that Brazilian journalists believed they had emulated the characteristics of the American model. However, the critical people suggested Brazilian journalism need a clear perspective on how to deal with foreign influences (Herscovitz, 2004). A study in 2008 explored what accounted for the success of foreign films in Singapore from 2002 to 2004. It showed that cultural similarities and the size of the domestic market of the films' home countries account for most of the success ( Fu \& Lee, 2008). 


\section{New technologies and its influences on media freedom}

As shown by Niall Ferguson, the rise of new media could change the dynamics of the political landscape. Recent empirical studies and historical events have given evidence for this hypothesis. A research done in 2012 has shown that the rise of social media activism led to established democracies behaving in an almost identical manner with their authoritarian counterparts. There has been an increase in internet censorship through practices such as banning, blocking, filtering (Dick, 2012). Brooten (2011) shows that the increased access to cell phones and the digital camera has fueled the demonstration led by the saffron-colored robes wearing Buddhist monks in 2007, which is later named the 'Saffron Revolution' (Brooten, 2011). Or in the Arab Spring, social media was used to mobilize the masses of protestors in Middle Eastern and North African countries (Khondker, 2011). Research has also shown how new media could influence journalism practices as well. Phillip (2010) shows that in the networked era, the spread of media "cannibalization" implies there must be a new standard for media accuracy and transparency.

\section{Culture and History - Media freedom}

As culture and history are two underlying factors for any kind of sophisticated analysis aiming at predicting the future and making sense of the current events (Vuong, et al., 2018), the culture and history of a country could indeed shape the extent of its media freedom. For example, Djankov et al. (2013) presented two theories about media ownership. Public Interest (Pigouvian) theory, inspired by the historical birth of the British Broadcasting Coroporation (BBC), says government ownership of media is desirable because: (i) information is a public good; (ii) strong increasing returns on provisions and dissemination of information; (iii) consumers are ignorant. By contrast, public choice theory posits that private and competitive media make the quality of information better, with several empirical data supporting it (Djankov et al., 2013). A look at the literature on how the culture and history of a country could influence the shape of media freedom reveals there is little research done in this area.

\section{A conceptual framework for the shape of media freedom}

Through a literature survey, it can be seen that there are four factors: culture and history, internal political environment, foreign influences, and technologies that might shape the sphere of media freedom, which is summarized in Figure 1.

Figure 1: Four factors that shape the extent of media freedom 


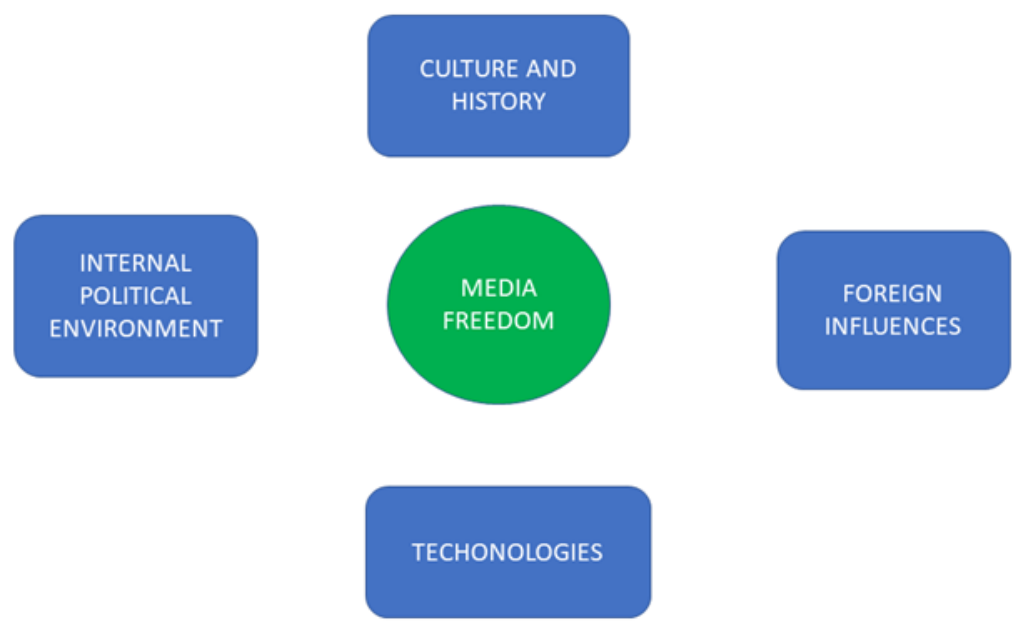

\section{Research Questions}

Through the conceptual framework presented above, we will seek to answer the following two research questions:

RQ1: To what extent is the media free in China and Myanmar?

RQ2: What are the factors that shape the extent of media freedom in the two countries?

\section{China's media and its relationship of (un)freedom}

\section{China's media environment}

It goes without saying that China is one of the most restrictive environments for media in the world. As explained in great detail by Richard McGregor (2010), the Chinese Communist Party (CCP)'s number one priority is to control every aspect of Chinese society; essentially, it is the notion of China itself is under controlled. McGregor wrote:

“The Politburo's overriding priorities lie elsewhere, ..., and controlling the very notion of China itself and the official narrative of its revival from an enfeebled power, broken apart and humiliated by foreigners, into a powerful state and resurgent civilization." (McGregor, 2010).

Hence, it is not surprising for all aspects of Chinese media to be controlled so strictly. The censorship body in China, the Central Propaganda Department, saw its tasks as nothing less than the matter of national security. The deputy director of the department from 1990-1998, Liu Zhongde once compared the head of the department with the Secretary of Defense in the United States or Ministry of Agriculture in the former Soviet Union (McGregor, 2010). According to Freedom House (2018), all media outlets must receive daily instructions from the department. The state has managed to control the telecommunications infrastructures, thus enabling a massive level of censorship: deletions of posts, instant messages, blocking news from even big media hubs such as the New York Times, YouTube, Facebook, Twitter, etc. In 2017, the Cybersecurity law finally came into effect, which has put more pressure on private businesses in China and intensified internet censorship. The restrictive media environment in China not only affects the businesses but also poses a tremendous financial challenge for investigative journalism (Cook \& Henochowicz, 2018). Not only does the Chinese government put so much restriction on the media, it even gets 
into the game of injecting the mediascape with its information. Cook and Honochowicz (2018) report that the Chinese government gave subsidies to private companies so that these companies put stories about their leader Xi Jinping and his visions on top of every news feed. This example shows just how adept and adaptive the CCP is using the new media for their interests.

\section{To what extent is the media free in China?}

In such a restrictive environment, is it possible to have some degree of media freedom in China? To answer this question, it is essential to establish the meaning of complete and absolute media unfreedom. North Korea comes to mind as a place where the government has successfully destroyed all traces of media freedom. Yet, some reports have shown there are DVDs, novels, books that get smuggled into the countries (Chesnut, 2007); therefore, there is a limited level of media freedom there. To find complete media unfreedom, one must come to George Orwell's 1984.

Although the CCP takes a great deal of interest in controlling the media, it is not possible to completely obliterate media freedom in the way the Party has done in Orwell's 1984. There are several reasons for that. First of all, the rise of the new media that allows for the lightning speed of information spread creates a new kind of problem of Chinese security: how to control the spread of rumors. It is in the interest of the CCP to maintain societal order and stability, which could be harmed by uncontrolled stories and fake news. Hence, the media is free to do their jobs in China to the extent that it could help counteract the spread of falsehoods and misinformation. In 2007, the Chinese central government initiated and passed the Freedom of Information Act (FOI), which strongly emphasizes the 'proactive disclosure of government information' (Snell \& Xiao, 2007); this phenomenon has puzzled the West. Xiao (2013), in his attempt to explain the puzzling passage of the (FOI), put forth the argument that the need to control the spread of rumours and misinformation is among the causes for the legislature. Another example of the freedom of media in China is the 13 first-class reportings of Chinese investigative journalists brought to the world by the Global Investigative Journalism Network in 2017 (GIJN Staff, 2018). These reports cover a wide range of topics from the misconducts of an autistic care center, kindergarten child abuse, pharmaceutical, financial fraud to mining pollution.

Another aspect of media freedom in China is the evolution of Chinese media to meet with the demand for sophisticated stories of the people at the same time, comply with the censorship standards imposed by the government. In recent years, there is an emergence of Chinese investigative journalism; an example is Caixin, a business publication known for its "aggressive and investigative reporting" has become popular (Cook \& Henochowicz, 2018; Wong, 2016). This shows just how hungry Chinese audiences are for news. In a study done in 2011 about the effect of media exposure to the perception of the people on labor-law-related issues, Stockman and Gallanger shows that as media in China becomes more commercialized, the media can provide persuasive and sophisticated messages to the audiences and yet conformed to the censorship of the government (Stockman \& Gallanger, 2011).

Another aspect of media freedom in China is the role of key individuals to expand the sphere of freedom in the county. In the case of the FOI act, Prof. Hanhua Zhou played a crucial role in getting the political environment in China to accept this act. He put the focus on informationization, economic growth, the building of E-Government and the emphasis on reusing 
government information for economic growth; all of them complies with government's policy and uncouple the FOI with the freedom of expression issue, thus avoiding the fear of the politicians over the incompatibility of the FOI with the Marxist-Leninist political system in China (Xiao, 2013). Xiao suggests the passage of FOI Act is the result of Prof. Zhou's role as "key individuals advocacy" and "policy entrepreneurship." Another example of the role of the individual in expanding the sphere of media freedom in China is the publication of Tombstone, a book about the famine caused by Mao Zedong's Great Leap Forward policy, in which, it is estimated that 3040 million people starved to death. Tombstone is written in secret over two decades by Yang Jisheng, a senior member of Xinhua-a official state news agency; it was published in 2008. If in the past, the response from the CCP would be to jail or even kill Yang, now, it merely bans the book from publication in mainland China, ignores the book and the author (McGregor, 2010).

Thus, the analysis above shows that there are three aspects of media freedom in China: the need of the government to control the spread of rumors and misinformation, the evolution of Chinese media to catch up with censorship and at the same time provide first-class investigative journalism and the role of individuals to push the boundaries of media freedom. However, it must be said that these aspects are vulnerable to the ever-growing power and sophistication of the Chinese government to control new media technologies; hence, it is vital to continue to fight to media freedom in China.

\section{Myanmar's media and its relationship with (un)freedom \\ Myanmar's media environment}

Before the political reform in 2010, which followed by a media reform in 2012, media is strictly controlled in Myanmar. The largest TV station owned by the Ministry of Information and Culture and the second-largest TV station owned by the Ministry of Military (Djanknov et al., 2003). Similar to China, there existed several censorship bodies in Myanmar: the Press Scrutiny Board and the Registration Division. All news had to be reviewed by the Press Scrutiny Board. After the reform in 2012, the initial years are the golden times for media freedom in Myanmar: journalists, activists, bloggers are released; the censorship organizations were closed down; there was an increase in freedom in writing about taboo subjects (Brooten, 2017). However, this golden time did not last long. As communal violence between Rohingya Muslims and militant Buddhists broke in Rakhine State, the government has intensified media censorship (Than, 2014). There is an increasing level of self-censorship, limited access to politically sensitive locations (Brooten, 2017), and detention of journalists (Washington, 2018).

In this picture, Brooten (2015) argued for the positive role played by the existence of Myanmar's exile media such as Burma News International, Democratic Voice of Burma, BBC, VOA, Radio Free Burmese. These media platforms were crucial for the flow of news that is relevant for the minorities in Myanmar, yet not reported as often as they should be in Western mainstream media (Brooten, 2011; Brooten, 2015).

It is also worth pointing out that Myanmar has just only come out of five decades of military dictatorship and has not fully recovered from that. Hence, as Kajimoto (2016) points out, the younger generation in Myanmar does not fully understand the concept of journalism and the role of journalism ethics. In this environment, the emergence of commercialized media and the rise in 
popularity of social media platforms among younger people are a legitimate cause of concern. How critically the people of Myanmar will read the news might determine the future of media freedom in Myanmar.

\section{To what extent is the media free in Myanmar?}

Myanmar is a more democratic country, Myanmar people indeed enjoy more media freedom than the Chinese people. This fact is supported by the Freedom House score mentioned at the beginning of this paper (Myanmar's Freedom House score is 31/100 while China's rating is 14/1000). However, recent political development in Myanmar shows that the progress in media freedom can be set back; Than (2015) described Myanmar's democratization as a journey of great expectations unfulfilled.

One of the key features of media freedom in Myanmar is the role played by exile media in allowing the marginalized groups to have a voice. In the debate on Myanmar's media freedom and reform, Brooten (2011) pointed out when there is too much focus of Western media on the issue of individual human rights and democracy; people could neglect the collective rights, social and economic rights. Framing the issue of Myanmar's media freedom on the understanding that all rights (individual, collective, social, cultural, etc.) must be balanced, she argued that the existence of Myanmar's exile media has allowed marginalized groups in the country to communicate with the world. According to Brooten's analysis, the work of journalists working for these exile media has contributed to the process of ethnic reconciliation of Burmese society.

\section{Factors that shape the extent of media freedom in the two countries}

Studying the case studies of media in Myanmar and China, one can realize four factors could play a role in shaping the extent of media freedom in the countries: internal political environment, foreign influences, culture and history, and technologies. These factors cannot be underestimated in any discussion of political economy (Vuong, 2014). These factors are summed up in figure 1.

Both China and Myanmar have their own unique culture and history and internal political environment; they determine mostly how much the media is controlled. In the case of China, the rule of the Communist Party of China and its effort to maintain a grip on every aspect of Chinese society mean a media that is censored and controlled (McGregor, 2010). In the case of Myanmar, the history of the long decades under military dictatorship is still haunting over the country, and recent events have set back the progress of media freedom (Bhatia, 2017).

However, with the development of communication technology, media in the two countries are changing too. In the case of China, even the state is adept at catching up with the development in media technologies; there is still a need for the state to control rumors and misinformation. Hence, the passage of the Freedom of Information Act in 2007 to the surprise of many Western experts (Xiao, 2013). For Myanmar, though right now, the traditional media such as radio, print newspapers, TV are the primary sources of news (Kajimoto, 2016), yet, with more internet penetration and access to smartphones, it is possible that the country can enjoy media freedom. Nonetheless, the problem of news literacy must be addressed as people in Myanmar are unfamiliar with the concept of journalism and journalism ethics. 
Foreign players could play a role in shaping media freedom, as well. For example, Brooten $(2015,2017)$ highlighted the role of international journalists in helping to bring the news about Myanmar to the world. However, it is also important to note that how international players frame the debate over media freedom and reform in these countries could have an impact. In the case of China, as the country gains more economic power and political power in the world stage, it is harder for foreign countries to influence the extent of media freedom in China. However, the highlights of world-class reporting of Chinese investigative journalists and their struggles done by Global Investigative Journalism Network could be helpful for the international society, if they decide to be more involved. Indeed, as China's status in the world will continue to rise (Todd \& Tse, 2018), the international society has a stake in the progress of media freedom in China.

\section{Discussion}

This research is still in a preliminary phase. The most severe weakness is the lack of a conceptual framework to analyze different cases in Myanmar and China. Another limitation is the fact that there is a wealth of research on media in China, yet research on media in Myanmar is still lacking.

The paper has looked at the media environment in China and Myanmar, the two countries that both have a history of political repression and are undergoing significant changes in the media landscape due to the rise of new technologies. Through this overview, the paper analyzes the shape of media freedom in the two countries. Specifically, the paper looks at how culture and history, internal political environment, foreign influences, and technologies have created a sphere of media freedom in each country.

\section{References}

Apodaca, C. (2007). The whole world could be watching: Human rights and the media. Journal of Human Rights, 6(2), 147-164.

Bhatia, R (2017). Does Democracy's Toehold in Myanmar Outweigh the Lives of the Rohingya? Freedom House. Retrieved from https://freedomhouse.org/blog/does-democracy-stoehold-myanmar-outweigh-lives-rohingya

Brooten, L. (2011). Media, Militarization, and Human Rights: Comparing Media Reform in the Philippines and Burma. Communication, Culture \& Critique, 4(3), 229-249.

Brooten, L. (2015). Blind Spots in Human Rights Coverage: Framing Violence Against the Rohingya in Myanmar/Burma. Popular Communication, 13(2), 132-144.

Brooten, L., \& Verbruggen, Y. (2017). Producing the News: Reporting on Myanmar's Rohingya Crisis. Journal of Contemporary Asia, 47(3), 440-460.

Carlin, D. (2013, 22 Apr). Prophets of Doom. Hardcore History Podcast. Podcast retrieved 21 May 2018 from https://www.dancarlin.com/product/hardcore-history-48-prophets-ofdoom/

Chestnut, S. (2007). Illicit activity and proliferation: North Korean smuggling networks. International Security, 32(1), 80-111. 
Cook, S \& Henochowicz, A. (2018). Investigative Journalism in China Is Struggling to Survive. Freedom House. $\quad$ Retrieved 17 May 2018 from https://freedomhouse.org/blog/investigative-journalism-china-struggling-survive

Dick, A. L. (2012). Established democracies, Internet censorship and the social media test. Information Development, 28(4), 259-260.

Djankov, S., McLiesh, C., Nenova, T., \& Shleifer, A. (2003). Who owns the media?. The Journal of Law and Economics, 46(2), 341-382.

Dutta, N., \& Roy, S. (2016). The interactive impact of press freedom and media reach on corruption. Economic Modelling, 58, 227-236.

Ferguson, N. (2017). The Square and the Tower: Networks, Hierarchies and the Struggle for Global Power. Penguin UK.

Freedom House (2018). China Profile. Freedom House. Retrieved 17 May 2018 from https://freedomhouse.org/report/freedom-world/2018/china

Fu, W. W., \& Lee, T. K. (2008). Economic and cultural influences on the theatrical consumption of foreign films in Singapore. Journal of Media Economics, 21(1), 1-27.

GIJN staff (2018). The Best Investigative Stories from China - 2017. Global Invesitgative Journalism Network. Retrieved 17 May 2018 from https://gijn.org/2018/01/04/the-bestinvestigative-stories-from-china-2017/

Guan, B., Xia, Y., \& Cheng, G. (2017). Power Structure and Media Autonomy in China: The Case of Southern Weekend. Journal of Contemporary China, 26(104), 233-248.

Hafez, K. (2002). Journalism ethics revisited: A comparison of ethics codes in Europe, North Africa, the Middle East, and Muslim Asia. Political communication, 19(2), 225-250.

Herscovitz, H. G. (2004). Brazilian journalists' perceptions of media roles, ethics and foreign influences on Brazilian journalism. Journalism studies, 5(1), 71-86.

Kajimoto, M. (2016). Developing news literacy curricula in the age of social media in Hong Kong, Vietnam and Myanmar. Journalism Education, 5(1),136-153.

Khondker, H. H. (2011). Role of the new media in the Arab Spring. Globalizations, 8(5), 675-679.

McGregor, R. (2010). The Party: the secret world of China's communist rulers. Penguin UK.

Phillips, A. (2010). Transparency and the new ethics of journalism. Journalism Practice, 4(3), 373-382.

Snell, R., \& Xiao, W. (2007). Freedom of information returns to China. Public Administration Today, 10(1), 44-7.

Stier, S. (2015). Democracy, autocracy and the news: the impact of regime type on media freedom. Democratization, 22(7), 1273-1295. 
Stockmann, D., \& Gallagher, M. E. (2011). Remote control: How the media sustain authoritarian rule in China. Comparative Political Studies, 44(4), 436-467.

Than, T. M. M. (2015). Myanmar in 2014: Great expectations unfulfilled. Asian Survey, 55(1), 184-191

Todd, B. \& Tse, B. (2018, 28 Feb). A new recommended career path for effective altruists: China specialist. 80,000 Hours. Retrieved from https://80000hours.org/articles/china-careers/

Vuong, Q. H. (2014). Vietnam's political economy: a discussion on the 1986-2016 period. WPCEB $N^{\circ}$ 14-010. Universite Libre de Bruxelles.

Vuong, Q. H., Bui, Q.K., La, V.P., Vuong, T. T., Nguyen, V. H., Ho, M. T., Nguyen, T. H. K., Ho, M. T. (2018). Cultural additivity: Behavioural insights from the interaction of Confucianism, Buddhism, and Taoism in folktales. Palgrave Communications, 4, 143. DOI: https://doi.org/10.1057/s41599-018-0189-2.

Vuong, Q.H. (2018). The (ir)rational consideration of the cost of science in transition economies. Nature Human Behaviour 2(1): 5, https://doi.org/10.1038/s41562-017-0281-4.

Vuong, Q.H. (2019). Breaking barriers in publishing demands a proactive attitude. Nature Human Behaviour 3(10): 1034. doi: 10.1038/s41562-019-0667-6.

Washington (2018). Myanmar: Detention of Journalists Threatens Press Freedom. Freedom House. Retrieved 17 May 2018 https://freedomhouse.org/article/myanmar-detention-journaliststhreatens-press-freedom

Wong, L. (2016, Oct 13). China Slaps Website With Two-Month Suspension From Media 'Whitelist'. Retrieved 21 May 2018 from https://www.rfa.org/english/news/china/caixinpunishment-10132016123546.html

Xiao, W. (2013). Freedom of information reform in China: Information flow analysis. International Review of Administrative Sciences, 79(4), 790-808. 